\title{
A tribute to Gerald M. Friedman
}

\author{
Larry D. Woodfork
}

Published online: 23 February 2010

(C) Springer-Verlag 2010

\section{Ladies and Gentlemen,}

You, the readers of the journal, hold in your hands the inaugural issue of Carbonates and Evaporites, re-launched under the imprimatur of Springer, its new publisher. It is a pleasure to write a short editorial focusing on the history of the journal, Carbonates and Evaporites, and the role of its founding and long time editor, Gerald M. Friedman (Fig. 1), and the Northeastern Science Foundation.



Fig. 1 Gerry Friedman speaking at the unveiling of a bronze plaque dedicated to the renowned early American geologist Ebenezer Emmons (1799-1863) on the campus of Rensselaer Polytechnic Institute, Troy, NY, 27 April 2006

A comprehensive tribute to Gerry Friedman's long and distinguished professional career, now spanning more than six decades, and his monumental contributions to geology is far beyond the scope of this narrative. Fortunately, if paradoxically, an illustrious and renowned person such as

L. D. Woodfork $(\bowtie)$

Northeastern Science Foundation,

Morgantown, WV 26505, USA

e-mail: woodfork@earthlink.net

Gerry Friedman, a living legend, indeed, an iconic international figure in modern sedimentary geology, does not require a recounting of his life and accomplishments in full detail to an audience as knowledgeable and enlightened as most of the readers of this journal. However, for students and others interested in a full account, I refer you to Gerry's autobiography, Saxa Loquntur (Rocks Talk): The Life and Times of Geologist: Gerald M. Friedman (published by the SEPM Foundation, Tulsa, OK) and Gerry's web site www.geraldfriedman.com.

In 1979, Gerry fulfilled a long-felt ambition by founding the Northeastern Science Foundation (affiliated with Brooklyn College), headquartered in Troy, NY, and began editing and publication of a quarterly journal titled Northeastern Geology and Environmental Sciences. As a labor of love, and at considerable personal expense, Gerry purchased and remodeled a large building in downtown Troy and named it the Rensselaer Center of Applied Geology (RCAG), which became in 1983 the official headquarters of the Northeastern Science Foundation. The RCAG building contained a large auditorium/lecture hall with modern audiovisual equipment, office space, extensive collections and displays of rocks, minerals and fossils from around the world and a large library collection of geological literature. Over the years, the RCAG has been a center of geologic research and education in the northeastern USA. A multitude of symposia, professional and scientific meetings, field trips, etc. have been hosted by the RCAG and Northeastern Science Foundation and a large number of diverse visitors from around the world have viewed the geologic and paleontologic collections and used the library.

Another ambition and labor of love was accomplished in 1986, with the first publication by the Northeastern Science Foundation of a biannual journal titled Carbonates and 
Evaporites. Gerry, again, was the editor of this journal from its first issue until the present issue.

This short vignette would be unforgivably incomplete without acknowledgement of the tremendous supportive role that his beloved wife, Sue Tyler Friedman, has played over the decades. Anyone who knows the Friedmans well will attest that Sue's indispensable role as Gerry's loving helpmate cannot be overstated. Now Gerry, well into his ninth decade, and Sue, with the concurrence of their children and the Board of Directors and staff of the Northeastern Science Foundation, have arrived at the conclusion that the time and circumstances are now such that Gerry announced his retirement and it is therefore prudent to dissolve the Northeastern Science Foundation and convey publishing rights for Carbonates and Evaporites, as well as the remaining inventory of back issues of the journal, to Springer.

So, ladies and gentlemen, on behalf of Gerry and Sue Friedman, their family, Anne Woods, and the Board of Directors of the Northeastern Science Foundation, we wish to thank all of the loyal subscribers and readers of Carbonates and Evaporites from 1986 to present for their support, and we wish Springer good luck and great success with their new journal, Carbonates and Evaporites, which we are confident will increase international readership and subscriptions.

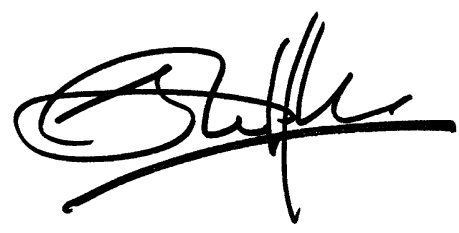

Larry D. Woodfork 